January 9, 2014

\title{
Dealing with Debt
}

\section{By Carmen M. Reinhart*, Vincent Reinhart** and Kenneth Rogoff***}

\author{
*Carmen M. Reinhart \\ John F. Kennedy School of Government \\ Harvard University \\ 79 JFK Street \\ Cambridge, MA 02138 \\ carmen reinhart@harvard.edu \\ **Vincent Reinhart \\ Visiting Scholar \\ American Enterprise Institute \\ 1150 Seventeenth Street, NW \\ Washington, DC 20036 \\ 347-255-6635 \\ vincent.reinhart@aei.org \\ ***Kenneth Rogoff - Corresponding author \\ Department of Economics \\ Harvard University \\ 1805 Cambridge Street \\ Cambridge, MA 02138 \\ 617-495-4022 \\ krogoff@harvard.edu
}

Revised version of paper presented at the NBER International Seminar on Macroeconomics, Riga, Latvia, June 27-28, 2014, Richard Clarida, Jeffrey Frankel, Francesco Giavazzi, and Hélène Rey, organizers. The authors benefitted from the comments of participants and especially our two discussants, Richard Clarida and Francesco Giavazzi, as well as Chenzi Xu and Stephanie Lo. Carmen Reinhart and Kenneth Rogoff thank the National Science Foundation (Grant No. 0849224) for research support. None of the above necessarily shares our views, nor do the institutions where we work. 


\section{Introduction}

Central to the discussion of economic prospects is the level of debt in major economies. After the severe 2008 global financial crisis and resultant recession in onehalf of the economies of the world, deleveraging in the private sector was modest and balance-sheet expansion in the public sector was massive. Indeed, over the long history considered by Reinhart and Rogoff (2009), the step-up in public debt to nominal GDP was without precedent in a window not containing a global war. Not only does the advanced-economy public debt buildup come on top of near-record private debt levels, but it also comes alongside record and near-record external debt levels and, in many countries, massively underfunded old age pension and health programs. Reinhart, Reinhart and Rogoff (2012) characterize the problem as a quadruple debt overhang.

The main contribution of this paper is to lay out a complete menu of options for renormalizing the level of public debt relative to nominal activity in the long run, should governments eventually decide to do so. In the first half dozen years after the 20072008 crisis, the real debate has rightly been about how fast and for how long to let debt/GDP ratios rise, not about cutting them. But a vision of longer-term options and issues is key to weighing alternative medium-term stabilization strategies.

There are basically two categories of debt reduction strategies. First, orthodox ones, the standard fare of officialdom, include enhancing growth, running primary budget surpluses, and privatizing government assets. Second, there are heterodox polices, including restructuring debt contracts, generating unexpected inflation, taxing wealth, and repressing private finance. Advanced countries have relied far more on 
such approaches than many observers choose to remember. Given the high starting debt loads that many governments bear (including unfunded pension liabilities and implicit insurance of private debt), a portion of them will likely choose from both parts of the menu in the years to come. In the event, there is ample precedent for orthodox and heterodox choices in the record of central government debt consolidations across 22 advanced economies since the Napoleonic War.

The choices are generally more generous and more diverse for debt that is governed by the domestic legal system (and therefore it is easier to manipulate the terms), owned by domestic residents (potentially making it easier for the state to impose its will should it wish to partially default), and is denominated in domestic currency (creating the option of partially defaulting in real terms through surprise inflation). Throughout, we will highlight where these distinctions are important.

The next section reviews debt dynamics in the window around the recent financial crisis through the lens of a longer historical perspective. Our interpretation is that the increase in debt among the advanced economies was large, owed importantly to discretionary actions by governments, and put major economies in unfamiliar territory. The debt surge has been followed by efforts to gradually stabilize debt at a very high level, with an eye towards eventually maneuvering a long-term gradual exit from that seldom-travelled region. We spend some time going through the history of the debt buildup, since its genesis and dynamics are germane to any ultimate resolution. The rest of the paper is organized along the menu of options, first considering the orthodox options that typically make up the core of programs of the International 
Monetary Fund and their official confederates. As discussed in section 3, the first and

by far most favored option is to have the economy grow faster, in real terms, than the expected market real interest rate on debt. ${ }^{1}$

To be sure, faster economic growth importantly contributed to scaling back debt loads after the three prior peaks in government debt loads in advanced economies over the past $2-1 / 4$ centuries. But those peaks were largely the byproduct of global military conflict. As Reinhart, Reinhart and Rogoff (2012) discuss, in the peacetime that followed, economic growth was bolstered by the re-integration of military personnel into the civilian sector and the application of technologies developed during the war. This time around, debt is the legacy of a global financial crisis, counseling caution in assuming that global economic expansion will pick up for the reasons emphasized by Reinhart and Rogoff (2009). ${ }^{2}$

We explore two possibilities why the interest rate on government debt might be pulled down rather than the growth rate of an economy pushed up outside a postconflict window. One argument, based on the Barro-Rietz model, argues that both consumers and the government are legitimately concerned about preparing for the outside risk of subsequent catastrophes, such as military conflicts, pandemics and

\footnotetext{
${ }^{1}$ We emphasize "expected" especially to distinguish cases where the trend equilibrium real interest rate is low from cases where the government is able to temporarily reduce the real interest rate through high rapid inflation. We emphasize "market" because in practice, highly indebted governments often institute a web of financial market controls and restrictions which, through accident or design, can have the effect of dramatically lowering effective interest rates paid on government debt, as Reinhart and Sbrancia (2014) have forcefully argued.

${ }^{2}$ There are many reasons why growth may be slow after a financial crisis, not least due to private-sector deleveraging. Frieden (2014) argues that debt crises naturally breed political discord as various parties struggle over which groups should bear the burden of the deadweight losses that financial crises generally entail. Mian, Sufi and Trebbi (2010) find empirically that political fragmentation increases after a financial crisis.
} 
financial crises. A second possibility is that governments repress private domestic finance to hold down the interest rate on government debt. If so, this is a wealth tax, not an $r<g$ bonanza.

As discussed in the fourth section of the paper, high debt loads can be pared back by actively running primary surpluses. Following Keynes, the surplus option is often polemically referred to as "austerity". (Indeed, even policies to gradually reduce budget deficits are nowadays often referred to as austerity.) At one extreme, Alesina and Ardagna (2009) argue that if the initial condition features a large, overweening government, then a government contraction emphasizing spending cuts, as opposed to tax hikes, may be expansionary. At the other extreme, DeLong and Summers (2012) argue that in a depressed economy, austerity is so inimical to growth, and cuts tax revenues so much (because of high fiscal multipliers and prolonged hysteresis), that it can lead to greater, not smaller, budget deficits. A middle ground, of course, is for the government to reign in large deficits slowly over many years after a crisis, with greater leeway allowed for debt used to finance productivity-enhancing investments in education and infrastructure.

As discussed in section 5, privatization, or selling government assets, generates cash that is especially useful for an economy with short-term liquidity problems. However, unless the private sector is more efficient than the public sector at providing the service being privatized, selling public assets has no first-order effect on the government's long-term budget constraint. If sold at too low a price, the effect may even be negative. 
We then turn to more heterodox policies that are often relied upon by nations in practice, but almost invariably frowned upon by transnational official institutions. They include restructuring debt, eroding it in real terms through unexpected inflation, or keeping its real cost low through financial repression.

To start, section 6 considers the possibility of debt restructuring and outright default. The chief reminder is that this is not the exclusive purview of emerging market economies. As Reinhart and Rogoff (2014) point out, before World War II, the outright write-down of debt in advanced countries was common and consequential. Debt restructuring and default more commonly hit external debt because the "softer" options of inflation and financial repression are not available. Even so, it sometimes occurred in the case of domestic debt with one notable episode being the abrogation of the gold clause by the United States during the Great Depression (Reinhart and Rogoff, 2009).

In the seventh section of the paper, we briefly consider unanticipated inflation as a form of de facto default, as was practiced writ large by countries such as Japan and France at the end of WWII. It was also a prominent feature across advanced countries during the 1970s, albeit on a lesser scale because debts were lower and inflation more moderate.

Next on the menu are wealth taxes, which Elmendorf and Mankiw (1999) list as one possible endgame to advanced-country debt buildups; Eichengreen (1990) explores efforts by European governments to institute lump-sum wealth levies in the aftermath of World Wars I and II, concluding that the efforts were undermined by political pressures and capital flight. We focus particularly on financial repression, which should 
be interpreted as a form of wealth tax more directly targeted at government debt holders. We argue that financial repression may be one of the major reasons why $r-g$ remained so negative after WWII, as Reinhart and Sbrancia (2014) discuss in great detail.

With that past as prologue, the conclusion ties together these threads.

\section{Recent debt dynamics in a longer-term perspective}

In the aftermath of the financial crisis of 2008, financial headlines grabbed attention with news of a massive expansion of government debt. The combination of government absorption of private mistakes, poorly performing economies that crushed revenue and raised nondiscretionary expenditures, and stimulus programs ballooned borrowing in much the way of prior crises (Reinhart and Rogoff, 2009, chapter 13). Equally attention-grabbing were subsequent reports of austerity programs in many countries intended to slow the speed of the debt buildup.

We proceed to review debt dynamics over the past seven years across a collection of countries from the historical perspective provided by our prior work. But two notes are necessary about the design of this discussion.

First, in part of this section we report summary statistics for countries and selected regions. That is, our unit of observation is a macro indicator for one country (or region) in a given year. We do not roll up to the global level or weigh the observations by their GDP footprint. This follows because the economic phenomena interesting to us - how governments behave around a financial crisis and in response to high debtwork at the national level or in sub-aggregates of economies that are similar. 
Aggregation is more appropriate for different questions, mostly related to how global markets clear. Working with country-years raises the possibility that Simpson's paradox (that disaggregated data yield different results than the same data aggregated) may arise. To us, that is because such aggregation obscures within-country dynamics and yields a mistaken answer to the question posed. Our preferred approach of countryweighting is, of course, the normal one in applications of this type, though others may be considered.

Second, throughout this paper we mostly use data from the International Monetary Fund (IMF), including its long history of public debt (IMF, 2013). ${ }^{3}$ Our earlier work employs a public debt dataset of our own construction, as documented in considerable detail in Reinhart and Rogoff $(2008,2009)$, which gives the key archival sources. The Reinhart-Rogoff dataset was in turn posted online and illustrated in Reinhart (2010). By and large, the later IMF work (including the first installment: IMF, 2010) follows the original sources we cited and matches up fairly closely with our dataset. The reality is that building such a dataset from many different original sources of varied quality involves numerous judgment calls, and of course may be subject to future re-evaluations.

The two panels of Figure 1 review the path of the general government balance (the bars) and its accumulation of gross public debt (the lines) for advanced and emerging-market economies, relative to nominal GDP. Both sets of scales span the same range, making it evident that the fiscal response to the crisis was an advanced-

\footnotetext{
${ }^{3}$ Besides the Historical Public Debt Database, two additional IMF sources are the World Economic Outlook (WEO) and Fiscal Monitor (FM).
} 
economy drama. Those were the nations with large financial centers, overextended private debt, and an enormous stock of wealth on paper that evaporated. Compared to emerging-market economies, the advanced economies have a more highly geared system of automatic stabilizers and a greater propensity to be active with their discretionary policy levers. The consequence was a 30 percentage point increase in gross debt to nominal GDP, pushing that ratio above 105 percent.

Emerging-market economies, in contrast, were not as dependent on financial activity. Those in the group that did fall into recession were mostly taken down by the problems of their trading partners. In fact, public debt only edged higher from a much lower starting point. ${ }^{4}$ That debt accumulates during a recession and an initially hesitant recovery is not surprising. After all, the logic of intertemporal smoothing of consumption is to run down assets or borrow when income falls temporarily below its longer-run prospects.

\footnotetext{
${ }^{4}$ That said, Reinhart, Rogoff, and Savastano (2003) demonstrate that emerging-market economies typically run into problems at lower public debt levels than do advanced economies.
} 
Figure 1

General government budget balances and gross public debt

relative to nominal GDP, percent

Advanced economies

Emerging-market economies

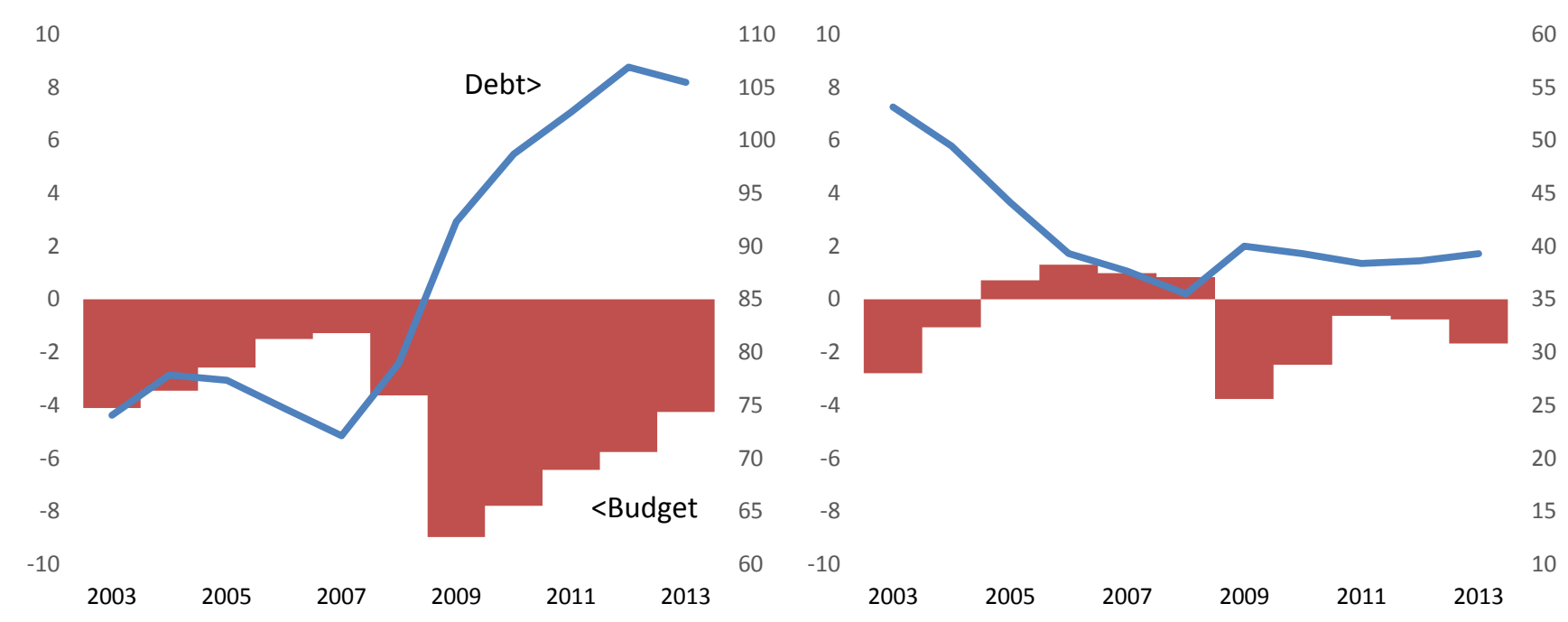

Source: IMF, World Economic Outlook (10/14).

Not all of the fallout from a severe financial crisis, however, is temporary. As Reinhart and Reinhart (2011) document across the worst financial crises of the second half of the $20^{\text {th }}$ century, ten years after a crash, the median level of real GDP per capita is 15 percent below the trend predicted from the ten years prior to the crash. As shown in Figure 2 for the most recent episode, in 2014 the IMF staff lowered its assessment of potential output growth in advanced economies compared to four years earlier. The right two columns of the table give the forecasts in the WEO for potential output growth in 2014 made in October 2010 and October 2014 for the Group of Seven countries. The growth of aggregate supply is never observed, but the latter (2014) estimate presumably comes closer to the truth, at least as IMF staff now understand it. In six of 
the seven nations, the IMF marked down the rate of growth of potential output over the four-year window, with declines of about $1 / 2$ percentage point or more in Italy, and Japan. $^{5}$ The one country where the IMF's assessment of growth prospects improved, Germany, is also the only one where gross public debt to GDP fell. Debt taken on when there were heady expectations of the expansion of aggregate supply would be more burdensome when prospects are marked down unexpectedly. Add to that some unexpected disinflation and the real burden of the debt is more considerable still.

Figure 2

Gross public debt (relative to GDP) and estimates of potential output growth

\begin{tabular}{|c|c|c|c|c|}
\hline \multirow[b]{3}{*}{ Country } & \multicolumn{2}{|c|}{$\begin{array}{l}\text { Gross public debt } \\
\text { to nominal GDP, percent }\end{array}$} & \multicolumn{2}{|c|}{$\begin{array}{l}\text { Potential output growth in } 2014 \\
\text { in the IMF World Economic Outlook, } \\
\text { percent }\end{array}$} \\
\hline & & & Forecast vin & as of: \\
\hline & 2010 & 2014 & Oct-10 & Oct-14 \\
\hline Canada & 84.6 & 88.1 & 1.94 & 1.87 \\
\hline France & 80.8 & 95.2 & 1.30 & 1.04 \\
\hline Germany & 82.5 & 75.5 & 1.16 & 1.50 \\
\hline Italy & 119.3 & 136.7 & 0.70 & -0.10 \\
\hline Japan & 216.0 & 245.1 & 0.82 & 0.36 \\
\hline United Kingdom & 78.5 & 92.0 & 2.03 & 1.73 \\
\hline United States & 94.8 & 105.6 & 2.12 & 1.90 \\
\hline
\end{tabular}

Source: IMF, Fiscal Monitor (10/14) and World Economic Outlook (various).

Instructive in understanding debt dynamics is the observation that a significant portion of widening budget deficits and their subsequent partial reversal owed to policy

\footnotetext{
${ }^{5}$ Most purely statistical techniques for estimating potential output would automatically mark it lower after a cyclical downturn, even if it were in fact exogenous. However, the IMF staff does not exclusively rely on a statistical filter to estimate potential output.
} 
decisions rather than the business cycle. The two panels of Figure 3 look at the changes

in actual general government budget balances (the horizontal axes) and their

discretionary component (the vertical axes) using the sample of advanced economies

available in the IMF Fiscal Monitor. ${ }^{6}$ The left panel plots the changes in these concepts

from 2007 to 2010, and the right pairs changes from 2010 to 2013.

Figure 3

Advanced economies: Change in actual and discretionary component of the general government budget balance

relative to nominal GDP, percentage points

2007 to 2010

2010 to 2013
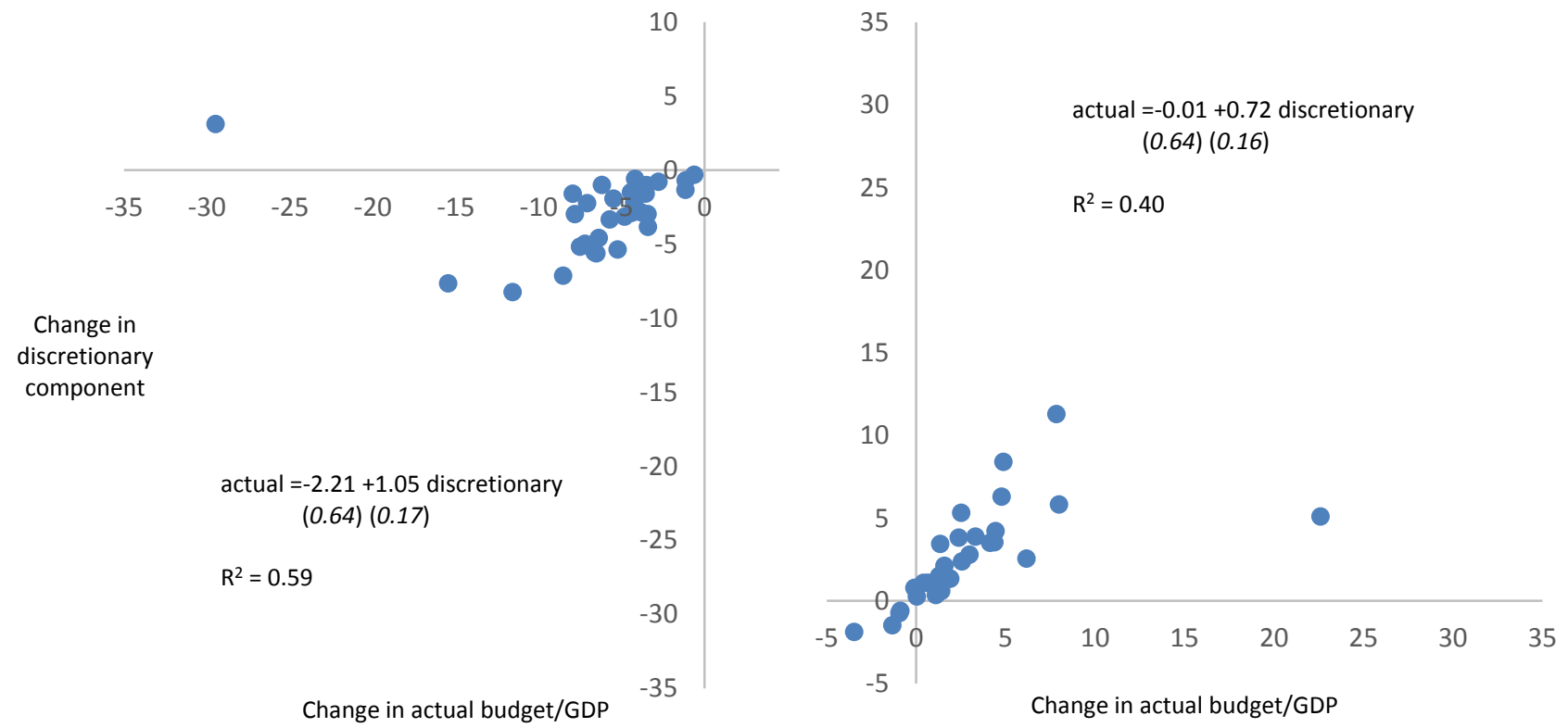

Source: IMF Fiscal Monitor (10/14).

\footnotetext{
${ }^{6}$ We use a chain rule to split the IMF estimates of actual, primary, and cyclically adjusted primary budget balances to identify the discretionary, cyclical, and interest-rate components of the budget. An explanation and the data for the 30 advanced economies plotted in the chart are given in Appendix A.
} 
At least according to IMF staff, the deterioration in government budget balances was predominantly a decision by governments, with the exception of Ireland given its marked depression in activity. Omitting Ireland, the simple regression between the two budget concepts shown in the inset suggests that budgets overall deteriorated 2.25 percentage points of GDP because of cyclical weakening across all countries and onefor-one with discretionary action within countries. ${ }^{7}$ We emphasize the distinction between discretionary and cyclical sources of the deficit because it is potentially important for understanding options to stabilize growing debt ratios. As the figure illustrates, the discretionary component was quite important in many cases.

The improvement from 2010 to 2013 follows the same script, with Ireland once again proving the exception. The changes are more heterogeneous, in that a simple regression explains less of the variation and has no role for a common contributory change in budget balances. Note that seven-tenths of discretionary changes pass through to budget balances in contradistinction to DeLong and Summers' (2012) result that, in theory at least, the pass-through might have been much smaller or even negative.

As we have already noted, there is little disagreement about the appropriateness of governments using fiscal policy to buffer the economic dislocations of the financial crisis. There is far more controversy about the consequences of later decisions to reverse budget deficits gradually. One line of thought is that in doing the latter, officials were leaving money on the table, especially given that borrowing costs were

\footnotetext{
${ }^{7}$ Reinhart and Rogoff (2009) note that, historically, the most important driver of large post-crisis debt buildups is the depth of the recession, not the strength of countercyclical policy.
} 
exceptionally low. Another possibility is that officials were considering more margins (such as risk management) or a longer horizon when considering the marginal costs and benefits of allowing high debt to expand even faster. This is not to say that the calibration in any given country was optimal after the financial crisis, nor does it fully explain why governments were apparently so reluctant to spend more on high-return infrastructure projects that, over the long run, would likely raise output enough to lower long-run debt-to-GDP ratios.

Striking to us is that governments tend to avoid prolonged stretches of high debt relative to GDP across countries and over periods of time (a point emphasized in Reinhart, Reinhart, and Rogoff, 2012). What some see as a missed opportunity might be a respect for precedent. In that regard, the cumulative density function in the upper panel of Figure 4 sorts the observations on advanced economies in the IMF historical database by the frequency of the debt-to-GDP ratio. ${ }^{8}$ Economies stayed under a ratio of 100 percent, around the current reading for the advanced-economy aggregate, 83 percent of the time. Even that may understate the aversion to high debt in the political economy, as observing country-years admits the possibility that the results are driven by long spells in a few countries.

\footnotetext{
${ }^{8}$ The country set is the same as in the Fiscal Monitor as listed in the appendix table. As previously explained, for this paper we are uncritical users of the IMF historical database, but in other work we start our sample in 1800. The first century of observations in the IMF database, the 1700 s, are mostly provided by the UK.
} 
Figure 4

Advanced economies: Gross public debt to GDP

Across all countries in all years

percent of sample

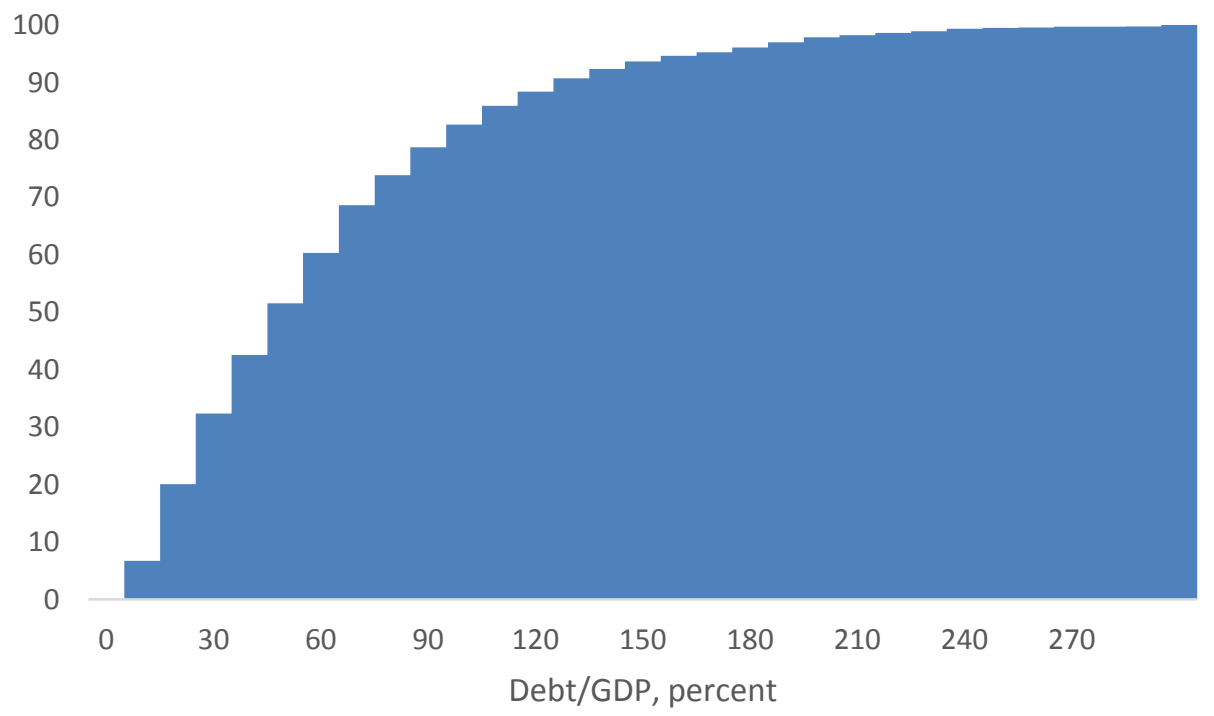

Across percentiles of all countries percent of sample

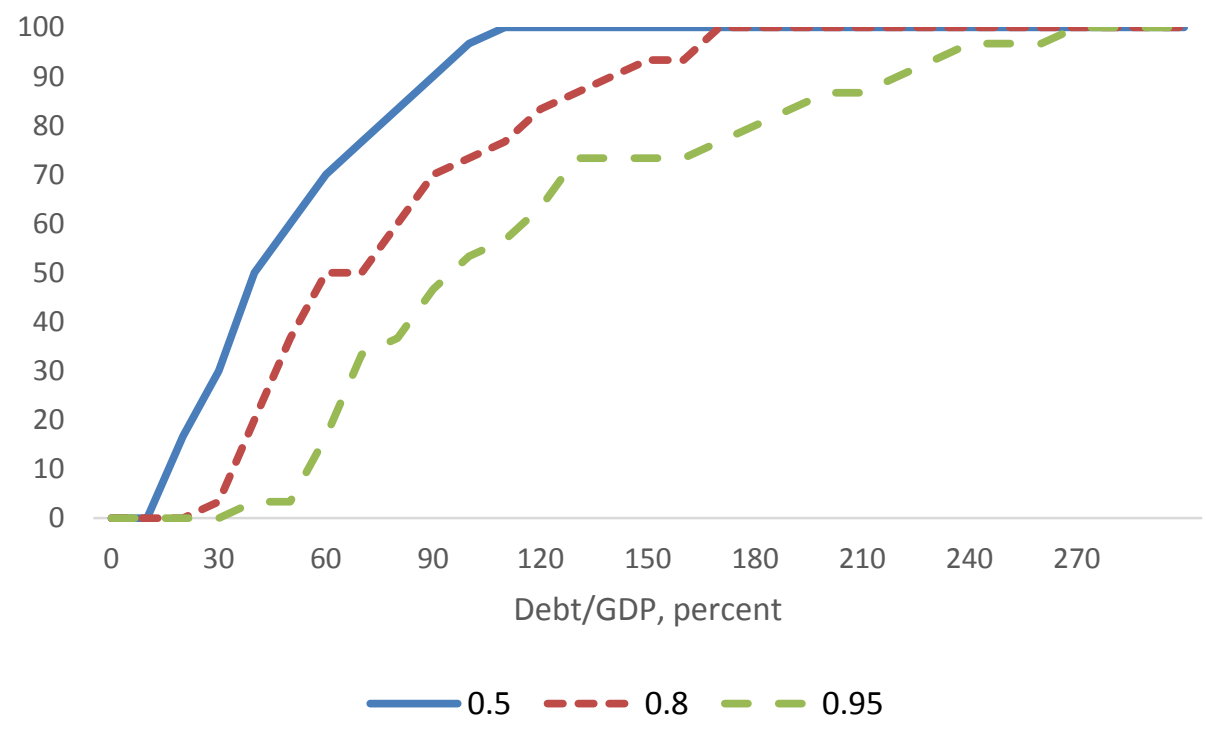

Source: IMF Historical Public Debt Database (2013). 
Indeed, as we have emphasized in earlier work (e.g., Reinhart, Rogoff and Savastano (2003) and Reinhart and Rogoff (2009)), country-specific factors - including history, institutions, the level of private and external debt as well as unfunded pension liabilities - are absolutely central to understanding any country's tolerance for carrying high public debt. Nevertheless, given that high-debt spells are relatively rare, it is important to consider cross-country data as well.

The bottom panel plots selected percentiles $\left(50^{\text {th }}, 80^{\text {th }}\right.$, and $\left.95^{\text {th }}\right)$ of the country distributions, which underscores the aversion to sustained high-debt levels revealed by the sample. The shallow dashed line sorts the $95^{\text {th }}$ percentile readings across the time series of 30 countries. It shows that 53 percent of the sample had a $95^{\text {th }}$ percentile reading of a 100 percent debt-to-GDP ratio. Put the other way, 47 percent of the sample had the government willing to tolerate that debt ratio or higher 5 percent of the time. ${ }^{9}$ Sustaining such a long stretch is increasingly unlikely. About 27 percent of the countries kept their debt ratio at 100 percent or higher for 20 percent of the time (the dashed line). Only 3 percent of the sample (one country, the UK) held the ratio that high for 50 percent of the time (the solid line). The Netherlands also posted a high debt ratio for much of the pre-Great War sample.

Empires are exceptional for many reasons, as emphasized in Reinhart, Reinhart and Rogoff (2012). For one, over much of their history, they enjoyed massive net revenues from abroad; in that sense, the right denominator for the UK and the Netherlands in the $19^{\text {th }}$ and early $20^{\text {th }}$ centuries would include some proportion of

\footnotetext{
${ }^{9}$ Read the difference between the c.d.f and 100 percent as the share of countries living with high debt with the frequency given by the relevant percentile.
} 
empire income. On the theory side, Lucas (1990) provides an elegant example of how scale might be another important return to an imperial power. As for revealed preference, the wars of the era showed that they and other powers assigned great economic and strategic value to colonial assets, so much so that the UK was engaged in military action during nine-tenths of the $1800 \mathrm{~s}^{10}$ The empirical evidence on direct returns to empire, narrowly construed, are somewhat more mixed. The returns estimated to the UK from its empire range from normal (Davis and Huttenback, 1988) to high Edelstein (1981). Madison (1989) judges that 15 to 20 percent of Indonesian net domestic product went to Europeans (primarily the Dutch colonial power) in the $19^{\text {th }}$ century.

With the age of empires behind them, current officials seem to be following in the footsteps of their predecessors. Governments tolerated high debt loads at a time of national duress but took steps to extricate themselves subsequently. Perhaps this just means that officials are replicating the timidity of earlier generations, or there may be others forces at work. Of course, it is possible and likely that debt tolerance has evolved over time, for example in response to financial globalization (see, for example Azzimonti, de Francisco and Quadrini, 2014). On the other hand, unfunded pension liabilities and government guarantees implicit in secularly rising private debt may have lowered public debt tolerance (see, for example, Arcand, Berkes and Panizza, 2012). Importantly, we note that Figure 4 does not take into account the maturity structure of

\footnotetext{
10 See the data in "Correlates of War" at http://www.correlatesofwar.org/. Accessed on August 20, 2014.
} 
public debt, which is of course an important factor is assessing vulnerabilities, as Rodrik and Velasco (1999) among others have emphasized.

We will now proceed to analyze this critical issue in greater detail by discussing seven approaches to debt reduction in turn: growth, austerity, privatization, restructuring or default, unanticipated inflation, wealth taxes, and financial repression.

\section{The favorite item on the menu: Growth above the interest rate}

Many scholars, including Barro (1979), Ball and Mankiw (1995), and Bohn (2008) have noted that in practice, some advanced-country governments, most notably the United States, have been able to pay down a substantial portion of their debt by opportunistically exploiting the differential between the interest rate on government debt and the growth rate of the economy. They largely treat this issue as a puzzle and a trap. They caution that a government running a debt-Ponzi scheme when $r<g$ might be subsequently faced with a sudden interest rate rise, necessitating a sharp and painful fiscal contraction.

It is convenient to break the problem into two parts. First, is it possible to raise growth to solve a debt problem? Alternatively, can the government simply rely on a very low interest rate to help facilitate the reduction in its debt-to-income ratio, even if growth is only normal? We will devote considerable attention to the $r$ versus $g$ issue since it is often central to the claim that advanced economies (small and large) are special.

The expanding body of evidence on the relationship between debt and growth, surveyed in Reinhart, Reinhart and Rogoff (2012), establishes that, on average, the 
growth of real GDP at very high levels of debt is below that at low levels of debt. ${ }^{11}$ In the event, virtually all the evidence is consistent with Reinhart and Rogoff's (2010a, b) original conjecture: In the upper tail of debt/GDP ratios, the average rate of growth is lower than in more normal times. ${ }^{12}$ This does not mean that an economy with high debt cannot engage in structural reforms to substantially enhance growth. Nor does it mean that a highly indebted country should eschew high-return infrastructure projects that might raise debt in the short run but lower debt-to-income ratios in the long run. It does inject a note of caution that the track record of how countries have grown with high debt is very mixed. And as a policy issue, it leaves one to wonder why growthenhancing measures were left on the table to be picked up when pressed by high debt loads.

The period immediately following WWII deserves special comment, since that war also marks the biggest global debt buildup since the Napoleonic Wars. As already noted in the introduction, growth performance after a war is bolstered by a number of special factors. These include the depth of output declines during the war (so that output is growing from a lower base in many cases), postwar demobilization of troops (implying a particularly rapid growth in the labor force), the arbitrage of bringing wartime military inventions into civilian use, and in the case of war-torn Europe and Japan, very high returns to investment in physical capital, especially given high levels of human capital. WWII followed on the tail of the Great Depression, when financial

\footnotetext{
11 For a discussion of earlier literature on debt and growth, see Checherita and Rother (2012).

12 A reader of Reinhart and Rogoff (2010b) would understand that a difference in averages in no way implies that a threshold is necessarily sharp.
} 
duress and weak growth likely slowed the pace at which basic scientific inventions were put to work in the civilian economy. Indeed, historians of productivity growth have long noted these factors were likely quite important in explaining why productivity generally began to slow in advanced countries during the 1970 s and 1980 s compared to the 1950 s and 1960s (see Ferguson and Wascher, 2004). Even considering all these factors, the debt and growth literature still finds that high debt is not positively associated with high growth, and many studies find the opposite.

Reinhart and Rogoff (2010b) note that comparisons between central government debt at the end of WWII and after the recent financial crisis miss an important feature of the rest of the economy. In current circumstances, total debt is far higher, both because of much higher state and local debt, and because of a massive inflation of private-sector debt. ${ }^{13}$ In 1946, public debt stood at 116 percent of nominal GDP. Private debt amounted to only another 45 percent, about half of which was in the nonfinancial sector. Essentially, fifteen years of depression and global conflict ground private credit to a halt. Subsequent scaling back by the US government allowed an easy rotation to a private sector eager to borrow. Not so now. Households, firms, and intermediaries have pushed private debt to well above that of the general government.

As Reinhart and Sbrancia (2014) argue and will be discussed in more detail later, exceptionally negative ex-post real interest rates, rather than exceptionally high growth, were a key factor in explaining how governments worked their debt down after WWII.

\footnotetext{
13 This draws on Buttiglione, Lane, Reichlin, and Reinhart (2014), which illustrates the massive overall leverage remaining in the global economy after the crisis and discusses policies for stabilizing public and private debt levels.
} 
Indeed, they find that if the US and UK had been paying even zero real interest rates (far below the growth rates their economies experienced), their debt-to-GDP levels would not have plunged in the ten years after 1945 as they in fact did.

Financial repression might be associated with lower government borrowing rates through two distinct mechanisms. First, increased regulation and restriction on finance raises the cost of private-sector intermediation. The resultant higher intermediation spreads imply a lower market rate is required to generate the same level of aggregate demand as previously. Second, if financial repression operates as a tax that impedes growth, or facilitates a higher public debt level, crowding out private capital, then real growth in the steady state will be lower than otherwise. By the canonical consumptionsmoothing equation, a lower rate of growth would be associated with a lower real short-term interest rate. ${ }^{14}$

A nuanced consideration of the consumption decision is worth exploring to see what other explanations there are for the exceptionally low and negative real interest rates on government debt that were so important in bringing down postwar debt. In particular, the fear of rare disasters (à la Barro, 2006, and Rietz, 1988) might explain both households' willingness to accept low interest rates and the government's preference for low debt levels. Barro (2006) shows that the outside risk of a very large fall in consumption due to war, epidemic, or other catastrophe can help substantially solve the Mehra-Prescott (1985) equity premium puzzle.

\footnotetext{
${ }^{14}$ Indeed, if households are risk averse, then a reduction in growth produces a more-than-proportional decline in the real rate.
} 
Much of the action in Barro's parameterization comes not from a rise in the required return on equity, but from a fall in the risk-free interest rate. Where the canonical stochastic growth model with power utility shows a risk-free real interest rate of over 3 percent for the standard parameter choices for risk, growth, and the variance of consumption (see, for example Obstfeld and Rogoff, 1996, Ch. 5), Barro finds that by introducing rare consumption disasters, the real interest rate falls to 1 percent. Barro calibrates his model by looking at the frequency of large output falls (15 percent or more) over a relatively short period, across 20 advanced economies. He finds the odds of a disaster are about 1.7 percent per year. ${ }^{15}$

Barro does not, however, consider at length whether rare disasters are likely to make the real interest rate negative (though he notes the possibility). Here we explore that idea in more detail. Of particular interest is the post-WWII period where, as we document in section 7, maturity-weighted average real interest rates paid on government debt were often significantly negative. The basic point can be expressed in the simplest version of Barro's model, which is the same as Mehra-Prescott (1985) with time-separable utility and constant relative-risk-aversion preferences. Exogenous output follows a constant trend, subject to both the standard log-normally distributed shocks and a unit-root "rare disaster shock" that follows a Poisson process. When a rare disaster occurs, there is a permanent one-time drop in the level (but not in the trend

15 In later work (Barro and Ursua, 2012), he extends the scope of his dataset, incorporates data on consumption in addition to output (since it is consumption drops that enter utility), and uses a less strict definition of disaster (10\% instead of $15 \%$ ). This produces the odds of an output disaster of $3.5 \%$ and of a consumption disaster of $3.7 \%$. We note that there is a considerable further literature on rare disasters and macroeconomics including for example Wachter (2013), who explicitly allows for time-varying disaster risk, an extension that is clearly quite relevant to our discussion here. 
growth rate) of output. The rare-disaster shock is asymmetric in that it is only a downside risk. The resulting formula for the "risk free" real interest rate is given by

$$
\text { (1) } \begin{aligned}
r=\rho+\theta \gamma-(1 / 2) \theta^{2} \sigma^{2}-p \cdot\left[(1-q) \cdot E(1-b)^{-\theta}\right. & \\
& \left.+q \cdot E(1-b)^{1-\theta}+q \cdot E b-1\right]
\end{aligned}
$$

(see Barro, 2006, equation 12), where $r$ is the "risk free" interest rate, $\theta$ is the coefficient of relative risk aversion, $\sigma$ is the variance of the (log-normally distributed i.i.d.) growth shock, $\rho$ is the rate of time preference, $\gamma$ is the trend (deterministic) growth rate, $b$ is the permanent downward shift in output when a rare disaster occurs, $p$ is probability of a rare disaster, and $q$ allows for the possibility of a haircut on "riskless" bonds in the event of a rare disaster. Empirically, haircuts on bonds are particularly important after wars (through default and inflation) although they are still very much a hedge against rare disasters overall.

Barro (2006) imputes the probability $p$ of rare disaster as 0.017 , with the other parameters in equation (1) being $q=0.4, \theta=4, \rho=0.03, \gamma=0.025$. The mean of $b$ is taken to be 0.29 , though to calculate the coefficient on $p$ in equation (1) of course requires knowing the full distribution of disaster outcomes, since the term $[(1-q) \cdot E(1-$ $\left.b)^{-\theta}+q \cdot E(1-b)^{1-\theta}+q \cdot E b-1\right]$ is highly nonlinear. (The expectation operator on the righthand side of eq (1) is conditional on the occurrence of a rare disaster.) Given these parameters and Barro's estimates of the historical distribution of $b$, the coefficient on $p$ in eq (1) is -5.3 , and the expected real interest rate (net of losses from default) $r$ is 0.035 (Table V, column 2, in Barro, 2006). Given that the coefficient on the rare disaster probability $p$ is -5.3 , raising probability $p$ from the baseline of 0.017 to 0.025 , the 
expected real interest rate then falls to $-0.007[=0.035-5.3(0.008)]$ (Table V, column 4, in Barro, 2006). Doubling $p$ to 0.034 would lower the expected real interest rate to $--0.055[=0.035-5.3(0.017)]$.

These calculations, of course, assume that the distribution of $b$ does not change as the probability of a rare disaster rises, and that the effect on the level of output is permanent. However, later work has allowed more general utility functions (Barro, 2009), time-varying disaster probabilities (Gabaix, 2012), and a richer version of the disaster shocks. In an appendix, we illustrate calculations of the sensitivity of the interest rate to the probability of rare disaster using Barro's (2009) generalized recursive utility model where the coefficient of relative risk aversion is not constrained to equal the inverse of the elasticity of intertemporal substitution. We also use the extended disaster probability distribution results from Barro and Ursua (2012) where they allow for a weaker threshold of a $10 \%$ output drop for rare disasters. The effect of changes in $p$ on $r$ falls somewhat (to between -1.54 and -3.26 instead of -5.3 ), but the basic qualitative point is robust: small variations in the disaster probability can generate a very large change in the real interest rate.

Mehra and Prescott (1988) expressed skepticism when Rietz (1988) first suggested rare disasters as an explanation for low real interest rates, arguing that expectations of outside events are too volatile and would imply a correspondingly volatile real interest rate. They suggest that events such as resolution of the Cuban Missile Crisis in 1962 should have had a huge impact on interest rates according to the 
Rietz model. ${ }^{16}$ Barro (2006) suggested that this is not necessarily the case because wars have very different implications for the riskless interest rate than do other kinds of catastrophes such as recessions, because defaults on government debt (either through outright default or high inflation) are much more common during wars. In fact, in the cross-country historical sample, the loss rate on bonds and stocks is roughly similar, whereas during depressions bonds have proven a much better hedge. Arguably, since banking crises and pandemics by nature tend to occur quite unexpectedly, the process governing expectations of these events may be considerably more stable.

The generation that experienced the Great Depression attached a significant weight to a recurrence for a very long time. In the years after WWII, savers and investors might well have long remembered that the boom that followed WWI was followed a decade later by a depression. The idea that fears of catastrophe might help explain low real interest rates after the Great Depression was already noted by Nordhaus (1974, p. 200). ${ }^{17}$ Given the experience of WWI, the influenza pandemic of 1918-19, the Great Depression, WWII - not to mention the deep recessions a number of countries including the UK and Sweden experienced in the early 1920s -- it would not be hard to believe that individuals in the post-WWII period had a particularly heightened

16 More recently, Julliard and Ghosh (2012) argue that the rare events explanation of the equity premium puzzle creates too much correlation across returns on different equities.

17 See Nordhaus (1974, p. 200). He writes: "What explains the dramatic fall in the cost of capital? The answer seems to me to lie in the general economic climate and in the gradual dissipation of the fear of a new Great Depression. For many years after the crash, investors justifiably worried about a repetition of those events. Even as late as March 1955, when the fear might reasonably have faded, the statement by Professor Galbraith that the Great Crash could repeat itself was sufficient to send the market into a temporary panic - or so he claims." Nordhaus's footnote 21 cites John Kenneth Galbraith, The Great Crash, 1929 (2d ed., Houghton Mifflin, 1961). 
fear of tail risks. Indeed, a number of crisis indicators suggest the postwar period was risky, albeit not as uniquely risky as the foregoing discussion might imply; see for example the estimates in Wachter (2013). ${ }^{18}$

To the extent that $r$ is much lower than $g$ because of fear of a catastrophic event that affects an entire economy, it does not necessarily follow that the government should just passively let the debt/GDP level run down during normal times without ever running a primary surplus. Assuming the government has the same assessment of catastrophe risk as the public, and since it will likely need to borrow massively in crisis (certainly in a financial crisis or a war), then there is every reason to want to steer debt back towards lower levels so as to avoid the risk of facing borrowing difficulties at precisely the moment where the value of being able to borrow is highest.

Other explanations that do not fit as neatly into the Barro-Rietz paradigm include changing portfolio characteristics of debt, a growing inequality in rich countries that created a greater pool of resources in high-saving wealthy individuals versus creditconstrained poorer individuals, an anticipated slowing in trend global growth, and an aging global population. (See the IMF World Economic Outlook, April 2014, chapter 4, for a suggestive breakdown of the different effects.) Certainly, one can imagine some of the same effects going on during the post-WWII period. However, even if growth in the decades after WWII was unspectacular compared to the potential growth rate, it was

\footnotetext{
${ }^{18}$ We should also note that the general idea that catastrophic events may long influence investor and market behavior is consistent with broader theories, for example Zhang, Brennan and Lo (2014), who argue that major catastrophic events can have a significant effect on risk aversion.
} 
hardly a slow-growth period. And contrary to today's slowing population growth, there was a population boom.

On net, the equilibrium market interest rate may have been lower than usual in the manner suggested by the rare disaster literature. However, as we discuss later, other factors, including especially financial repression, may have been at least as important, if not more so, especially after World War II. More recently, high saving by emerging markets and aging advanced economies have also been important factors. ${ }^{19}$

\section{Primary budget surpluses}

A second class of options for dealing with high debt levels is to engage in active policies to return debt to normal levels. Notwithstanding the apparent experience in Europe from 2010 to 2013, the empirical literature on debt finds that there is a positive correlation between the size of the primary surplus and the level of public debt relative to GDP. In his classic paper, Bohn (1998) finds a strong and significant relationship in the United States using a long historical time series, even after controlling for business cycles and temporary government spending surges, for example due to wars. ${ }^{20}$

Barro (1979) argues that optimal debt management policy should aim to smooth tax distortions over time, in a fashion very similar to the permanent income hypothesis of consumption smoothing. Holding government spending constant, it is optimal to run deficits during a recession and surpluses during an expansion when welfare could better withstand the distorting effects of higher tax rates. During wars, governments run

\footnotetext{
${ }^{19}$ For example, see Bernanke (2005) and Caballero (2006). In his extensive survey of the literature on fiscal sustainability, Tanner (2013) also concludes that the casual evidence suggesting governments can rely on $r-g$ being negative absent financial repression is specious.

${ }^{20}$ See also Mendoza and Ostry (2008), Ghosh et al. (2011) and Mauro et al. (2013).
} 
deficits because current government spending is far above its normal "permanent" level. By the same logic, the government should also run surpluses during peacetime when government spending is low relative to its permanent value. Importantly, the government would not necessarily run a surplus just because debt is high.

Blanchard (1984) and Bohn (1998) point out that this simple rule has to be modified when there are limits to the share of GDP the government can raise as tax revenues. In this case, high debt-to-GDP ratios enter the calculus independently through a precautionary savings motive. More generally, we have already seen that empirically, even advanced-country governments cannot assume they always have access to markets no matter how high their debt levels (for example, the case of IMF bailouts of the UK and other advanced countries from the 1950s to the early 1980s).

An important failing of the extant empirical literature is that, due to data limitations, it is difficult to fully take into account the larger debt picture in the economy, including off-balance-sheet obligations of the government and private debt, which may become a public responsibility at a time of stress. ${ }^{21}$ Obstfeld (2013) argues that the growing size of the financial systems reinforces the need for governments to observe fiscal prudence, so as to be able to credibly backstop them in the event of a crisis.

Here, it is important to recall the decomposition of the budget change provided in Figure 3. According to the regression line, budget balances relative to GDP from 2007 to 2010 deteriorated one-for-one with discretionary acts, with another 2-1/4

\footnotetext{
${ }^{21}$ This is why crises tend to occur as "twins", in the terminology of Kaminsky and Reinhart (1999).
} 
percentage point worsening attributable to other factors, presumably the financial crisis and the attendant recession. That is, deficits were partly active decisions and those decisions were partly unwound from 2010 to 2013, when discretionary decisions contributed to 70 percent of the improvement in budgets relative to GDP, on average. Moreover, "austerity" is hardly a long-run trend, at least in the sense of a shrinking government. As Figure 5 portrays, the footprint of government spending as a share of GDP for the advanced economies tracked by the IMF expanded from around 20 percent Figure 5

Select advanced economies: Government expenditure relative to nominal GDP, percent

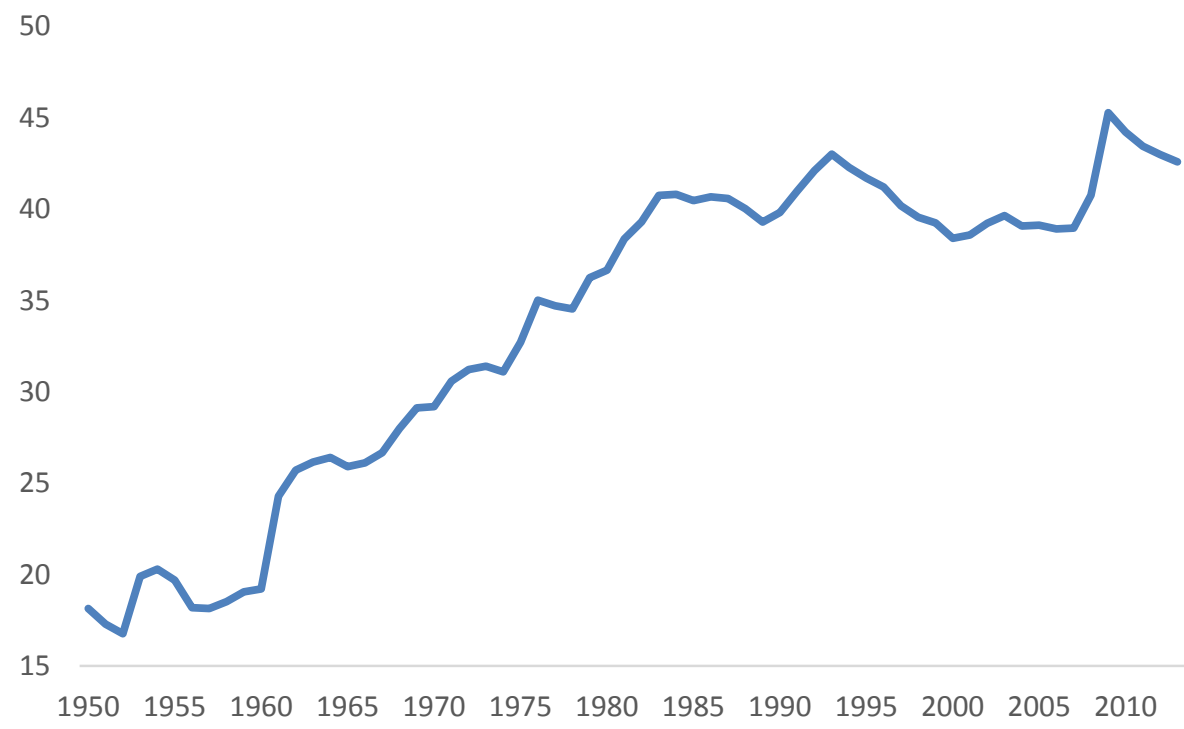

Source: IMF Fiscal Monitor (4/14).

in the early 1950 s to around 40 percent in the 2000 s. As a result, the recent downtick only reverses about one-third of the sharp increase associated with the immediate aftermath of the 2008 financial crisis. 
When a government has high debts, it may need to run primary surpluses either because it is forced by markets, or, as is more often the case of the richest advanced economies, because the government chooses to aim for a lower debt trajectory in order to maximally preserve its option to ramp up debt in a severe crisis. The real debate surrounding austerity should center on timing and tactics.

As already noted, DeLong and Summers (2012) argue that in some circumstances, particularly when the economy is in a liquidity trap, austerity can be selfdefeating and even likely to lead to higher deficits. Their argument centers on hysteresis in employment effects. When governments attempt to rein in debt during a period of weak employment, a greater number of workers become permanently estranged from the labor force, implying a fall in long-run trend output and in government revenues. ${ }^{22}$

Alesina and Ardagna (1998) assert that if done in a way that features reductions in government spending rather than tax hikes, austerity can actually lead to higher growth at the same time as it sharply reduces deficits. Their world is one where governments have become large, overweening and inefficient. In this case, austerity measures to boost long-term efficiency portend a long-term fall in tax rates, thereby energizing investment and confidence. To get the extreme result that contractionary fiscal policy might actually raise output, they implicitly allow for the fact that when a fiscally weak government tightens expenditure policy, it frees the central bank to follow

${ }^{22}$ The DeLong-Summers analysis, of course, does not take into account Schumpeterian creative destruction that occurs during recessions that has positive hysteresis effects. If the financial crisis itself ultimately traces to severe credit-boom-induced distortions, some restructuring is necessary in any event. 
a looser and more expansionary monetary policy. The IMF (2010) basically reaches the same conclusion, although it places greater emphasis on the key role of expansionary monetary policy in this process. An important implication is that if an economy is in a liquidity trap, the case of expansionary fiscal consolidation may be significantly less plausible.

The Alesina-Ardagna and DeLong-Summers analyses have some bearing on timing and strategy in a fiscal consolidation. In successful Alesina-Ardagna-type fiscal consolidations, there is a virtuous feedback effect, so that as growth is enhanced, the reduction in debt is more than proportional. In the DeLong-Summers example, austerity is self-defeating, and not only lowers the path of income but raises the path of debt. Presumably, in normal times, austerity does lead to a lower debt-to-income ratio, though perhaps not one for one. Regardless, fiscal consolidations usually involve intratemporal, intertemporal and distributional tradeoffs and other active policies for bringing down debt.

\section{Privatization}

Privatization of public assets, such as state-owned utility companies, land, etc. is often included in formal programs of official institutions with debt-strapped governments. It is important, however, not to confuse potential efficiency gains from privatization with genuine improvements in the government's long-run budget constraint. If, say, the government runs a utility as efficiently as a regulated privatesector monopoly would, then there are no efficiency gains. Even if the government succeeds in getting a fair price for its asset, it loses in expected revenues whatever it 
gains in short-term debt reduction. Privatization can be quite useful as one tool for dealing with acute short-term liquidity problems, but unlike the other policies considered here it does not necessarily relax the government's long-term budget constraint.

This suggests that there are two possible channels for real consequences of privatization. For one, the government may be a poor custodian of its assets, including the obvious possibility of corruption that may be part of our sample or waste associated with rent-seeking to find officials' favor. Moreover, officials are often limited in their ability to achieve the appropriate allocation of resources by binding procurement regulations and complicated labor rules. That is, a government-run enterprise can be thought of as the combination of an efficiently run business less a regulatory burden to achieve other policy goals. Selling the asset provides the opportunity to rethink those policies and arrive at a more efficient national outcome.

A second possible channel is that privatization can enhance the liquidity of the government's balance sheet by converting valuable but highly illiquid assets, thereby strengthening the government's ability to withstand speculative debt attacks. This is a legitimate question that requires further study. 


\section{Debt restructuring and default}

The history of sovereign default is dealt with in great detail in Reinhart and Rogoff (2009), including both defaults on external debt (which they define as debt governed by foreign law) as well as domestic debt (debt governed by domestic law).

For debt that is owed to foreigners, denominated in foreign currency, and adjudicated by foreign courts, the menu of options is far more limited than, say, for the case when debt is owed to domestic residents, indexed in domestic currency, and adjudicated by domestic law. By contrast, for external foreign-currency debt, when a country loses market confidence, and where no international bailout is available, default and debt restructuring can become a country's only option; it is not possible to inflate away foreign-currency debt by printing money. (Clearly, the issue is fundamentally the same for individual countries within the euro system.)

Foreign courts are also far less inclined to do a country's bidding. If US debt in the 1930s had been adjudicated by British law, would courts have allowed abrogation of the gold clause? (The gold clause guaranteed US Treasury debt holders the option of being paid in gold at $\$ 20$ per ounce instead of currency.) Foreign creditors cannot be bullied the same way as domestic bondholders when, for example, regulations and restrictions are put in place that force residents to hold government debt at far below the rates they would command in an unfettered market.

When debt is foreign controlled and foreign-currency denominated, countries face a rollover risk. With domestic debt, the central bank (or treasury as the case may be) can always print money to buy back maturing debt. Because debt denominated in 
domestic currency is far less vulnerable to rollover risk than foreign-currency debt, it generally affords countries a broader range of options, from adjusting primary balances, to relying on growth, to various forms of wealth taxes.

Even though governments that issue debt in domestic currency can never be forced into technical default by markets, they are, of course, still vulnerable to inflation risk and to nominal interest rate spikes should inflation expectations become unanchored. The naïve argument that inflation expectations can be perfectly anchored with inflation targeting without jeopardizing the central bank's ability to deal with rollover risk is explored by Aguiar, Amador, Farhi and Gopinath (2013). In fact, in their model, there is a tradeoff between maintaining inflation credibility and eliminating rollover risk for domestic debt. In the case where inflation targeting is too rigid, the country faces rollover risk because the central bank is not able to print money as needed to prevent a rollover crisis. In the case where there is no anti-inflation commitment, the country avoids rollover risks entirely, but is faced with a high, timeconsistent rate of inflation.

Under the assumptions of their model, the optimal policy is to aim for an intermediate case where expected inflation is relatively low (although above the optimum with commitment), but with sufficient flexibility to eliminate rollover risk. Some have argued that in the special case of an economy in a liquidity trap, the tradeoff disappears, since, at the zero bound, the government can issue currency to soak up any 
debt, without raising inflationary expectations. ${ }^{23}$ This argument is correct in the small but not necessarily in the large. On the one hand, if the government's anti-inflation commitment is strict, then a sufficiently large rollover problem will still force the central bank into a corner where it cannot continue providing liquidity without sacrificing its (assumed very strict) inflation commitment. On the other hand, if the inflation commitment is not strict, then the currency is still vulnerable to jumps in inflation expectations when the private sector coalesces on solvency concerns. Put differently, quantitative easing $(\mathrm{QE})$ is not an unlimited check-writing option for dealing with a collapse in debt confidence unless the central bank is willing to risk a very sharp rise in inflation expectations.

Other than inflation, do advanced countries default? Of course, as Reinhart and Rogoff (2009) show, many of today's advanced countries once defaulted routinely on external debt in earlier historical eras, and a number of the combatant countries defaulted in WWII, notably Japan and Germany. As Reinhart and Rogoff (2014) show, during the 1930s, there were also massive defaults on WWI debts owed to the United States government by the UK and France among others, and a number of Commonwealth countries defaulted on similar debts to the UK. Although the political economy of these debts was arguably somewhat unique, and the defaults did not appear to dramatically impair the borrowers' access to private markets (perhaps

\footnotetext{
${ }^{23}$ See, for example, Krugman (2014), who notes that Chinese holdings of US debt are not large enough to cause a problem, though it is far from clear what broader reaction might accompany a large-scale foreign central bank sell-off.
} 
because private debts were viewed as de facto senior), they nevertheless constitute very clear cases of default.

Qian et al. (2011) point out that while no advanced country has engaged in outright default between WWII and 2010, there were a number of close calls requiring IMF bailouts, notably of the UK in 1956, 1967 and 1976. So even before Greece later defaulted during the Eurozone crisis, a number of advanced economies found themselves constrained by markets, in contrast with the glib assumption that "advanced countries do not default." 24

As advanced-country government debt and old age pension obligations continue to expand, and as inflation-targeting regimes become more rigid, it remains to be seen whether all advanced countries have permanently "graduated" from outright debt default, using the terminology of Reinhart and Rogoff (2009).

\section{Unanticipated inflation}

As long as debt is denominated in domestic currency, then in principle inflation is always an option for substantially reducing debt. The option of inflating away debt is, of course, sensitive to the maturity structure of the debt, the underlying institutions that affect price rigidities, and the speed at which monetary authorities can accelerate the prices of goods and services. In the extreme event where all government debt is very short term, a government pursuing this option must generate a large sudden burst of inflation. Otherwise, private agents will anticipate the inflation burst as they roll over

\footnotetext{
${ }^{24}$ Of course, since 2010, Greece has defaulted on both public and private debts, several Eurozone countries have had their official debts restructured, and Cypress engaged in a restructuring that included a haircut for bank depositors.
} 
maturing debt and demand a proportionately higher nominal interest rate to compensate.

Even a very strong anti-inflation-targeting regime can break in the face of strong enough government-spending pressures. Entering WWI, most of the industrialized world adhered to the gold standard, an approach that had preserved long-run global price stability for the greater part of five centuries. But the exigencies of WWI induced countries to abandon the gold standard, while others engaged in highly inflationary macroeconomic policies. Whether inflation can be an endgame to modern peacetime debt buildups is an open question, but it remains on the table. Worrisomely, this is an option that would not be debated in public (thereby undercutting any benefits from its unexpected nature) but rather put into effect by central banks.

\section{Wealth taxes and financial repression}

As we have already noted, wealth taxes could be included in the full spectrum of tax policies that governments use to expand their primary surplus. We treat them separately here only in that by issuing a significant lump-sum tax on the stock of wealth, governments can deleverage at a far faster rate than by taxing the flow of income. The IMF Fiscal Monitor (October 2013) discusses the idea of implementing a $10 \%$ wealth tax in Europe as a mechanism for dealing with Europe's overleveraged economies, although it reaches cautious conclusions.

Financial repression, broadly defined, appears to be a far more commonly used, subtler, and quantitatively significant form of wealth taxation. Contemporary discussions of dealing with debt seldom acknowledge that the widespread system of 
financial repression that prevailed worldwide from 1945 to the early 1980s likely played an instrumental role in reducing or liquidating the massive stocks of debt accumulated in many of the advanced countries during WWII, the United States inclusive.

Repression is the mechanism by which governments can enjoy differentials between the interest rate and the growth rate far in excess of what market-based risk considerations would justify. ${ }^{25}$ Even during the 1970 s, when inflation clearly had a large unanticipated component (it certainly took much of the economics profession by surprise), financial restrictions, such as Regulation $Q$ in the United States, likely had a significant role in slowing private-sector adjustment to high inflation. This slow adjustment, in turn, allowed the government to pay far lower real interest rates than it might have had to do otherwise.

Reinhart and Sbrancia (2014) developed a new detailed database on the characteristics and the composition of government debt for 12 countries over 19452008. These data on the public debt portfolio reflect the actual shares of debts across maturities, as well as the shares of marketable versus nonmarketable debt (the latter involving both securitized debt as well as direct bank loans). The comprehensive scope of the data allows them to quantify the role played by financial repression.

Their year-by-year calculations measure the lessened real value of coupon and principal payments on debt owing to the cumulative toll of inflation. That is, a burst of inflation lowers real payments over a horizon defined as long as the longest-maturity

\footnotetext{
${ }^{25}$ Why use the term "repression," which might be taken pejoratively? In part, this is out of respect of the originators of the term, McKinnon and Shaw. In part, it treats the language used by official institutions symmetrically. For decades, emerging-market economies placing restrictions on capital flows or other financial market activity were deemed repressive.
} 
outstanding security. Apportioning the cost of inflation across the entire debt stock explains why the benefits of inflation stretch for so long (as opposed to the calculations in Hall and Sargent, 2010, for example). Also, consistent with the computational model of Hilscher et al. (2014), unexpected inflation gains far more traction when teamed with financial repression.

Figure 6 provides a snapshot of some of the evidence for a subset of the countries presented there. The left bars provide information on those economies

Figure 6

Incidence and Magnitude of the Liquidation of Public Debt, 1945-1980

\section{Liquidation years}

share of total, percent

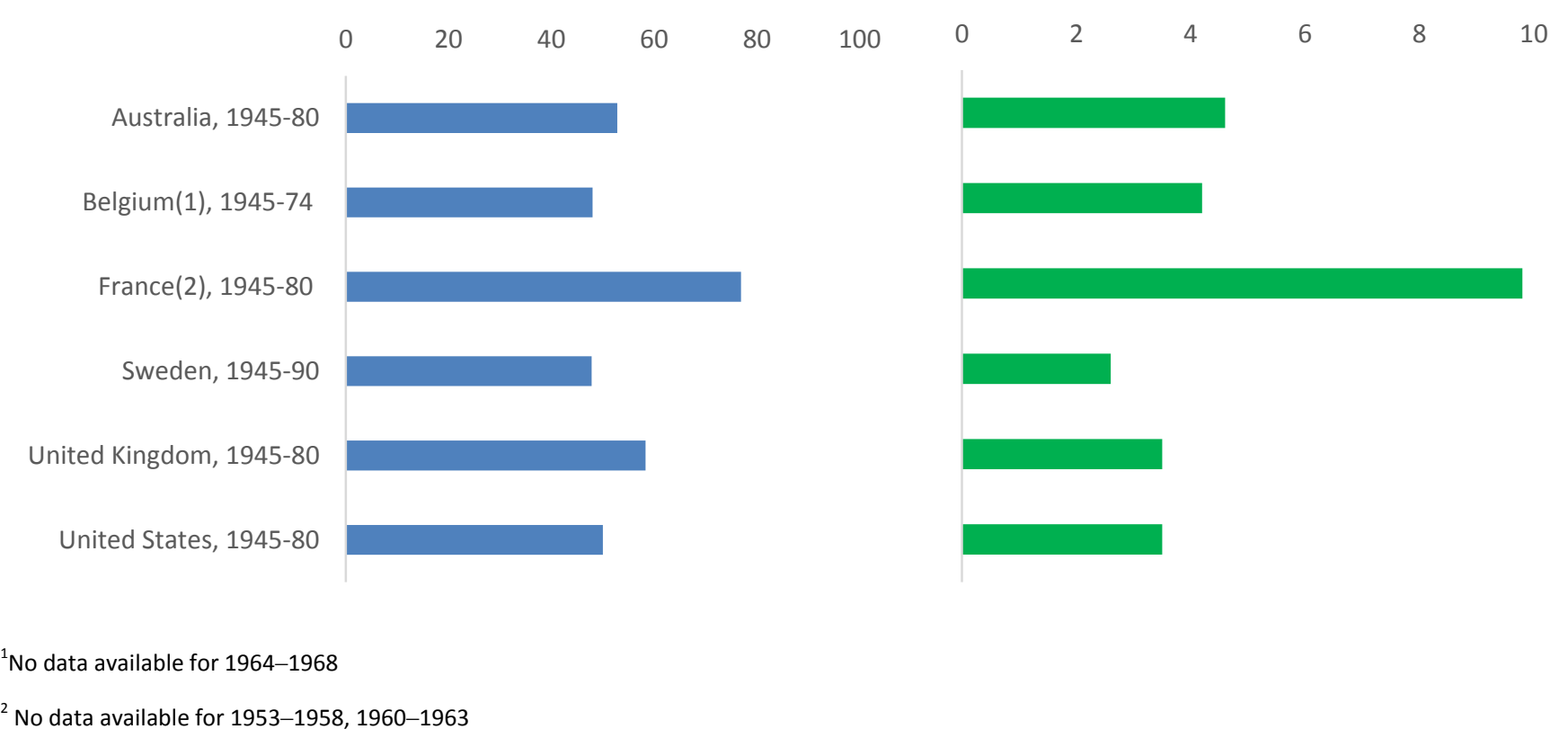

Average negative real interest rate in liquidation years, percent 
Germany and Japan did). Instead, they lowered debt loads in a slower grind by taxing government bond holdings. The bars at the left graph the share of the years in the sample in which outstanding real levels of debt fell because of a negative return on that debt.

The bars at the right plot the average negative real interest rate in those "liquidation" years. As is evident, these advanced economies spent a considerable share of this postwar period eroding the real value of their outstanding debt, with negative real rates averaging more than 2 percent (in absolute value). In France, about threequarters of the thirty-five years immediately following the war saw a steady drain on the wealth of bondholders, with the real rate averaging around 9 percent in those years, not much different in magnitude than the wealth tax that the IMF discussed so gingerly in 2013.

\section{Historical perspective on debt reduction}

We have shown here and in earlier related research that in practice, advancedcountry governments have used a far wider variety of methods for bringing down high debt levels than is commonly remembered. Heterodox methods such as debt restructuring, inflation, and financial repression have all been used on a large number of occasions. Can advanced-country governments simply rely on growth in excess of the interest rate to painlessly bring down exceptionally high debt overhang over the long run? The historical record is not necessarily kind to this view, as the mechanisms that create this wedge can sometimes raise risks and dampen growth. An important agenda for future research is to try to do an accounting of how debt has been brought down in 
different historical episodes, apportioning debt reduction across the different categories on the debt-reduction menu. Unfortunately, a comprehensive classification and breakdown is well beyond the scope of this paper. We do note, however, that our dataset on historical debt/GDP ratios over the past 21\%/4 centuries shows dozens of advanced-country episodes where debt/GDP ratios have come down on a sustained basis, say by fifteen percent for over a period of five years. Despite backdrops that were arguably more favorable than current circumstances, orthodox policies appear to have been insufficient in a significant proportion of the cases. Much more work is needed, however, to develop a more finely-graded classification.

\section{Conclusion}

Fiscal policy has many complex effects on the economy, and as Barro (1997) emphasizes, it is not easy to reduce their effects to simple aggregate-demand analysis. What the government spends its resources on and how it chooses to tax are critically important issues. It is misdirected to approach managing the primary balance absent a broader efficiency discussion on the costs and benefits of government spending and taxation. And in any such comprehensive assessment higher moments that affect risk potentially have significant impacts on private and public behavior.

Overall, the theoretical literature finds that there is cause for taking into account the effects of very high debt on the capital stock, growth, and risk. Perhaps, the most important motivation for preserving prudent public debt levels is the one Obstfeld (2013) exposits: governments are the last line of resort in many situations, and it is 
important to maintain the option value of being able to issue sudden large bursts of debt in response to catastrophes (war, financial or otherwise).

Officials act that way. They do not lightly take on exceptionally high debt loads. If circumstances dictate otherwise, they typically try to stabilize the growth in debt as the opportunity permits, with the aim of bringing it down (relative to income) in the long run. Examples include both the orthodox policies listed in every communique of the G-7 and G-20 and the heterodox ones amounting to wealth confiscation that have been often practiced in the past. Indeed, the message from dozens of episodes of significant debt reductions in advanced economies since the Napoleonic War is that everything is on the table.

Debt write-downs after the 2008 crisis could have been accomplished before private-sector mistakes were assumed by governments. Now, they seem inevitable for some countries after that fact. The most apt description of current circumstances comes from John Foster Dulles, writing in 1922 about Allied debts built up for a global event that, in retrospect, seems wasteful on a higher order even compared to the financial crisis of 2008. Dulles explained that it was time "...to clear away paper debts and credits which can never be collected, but which, by their existence, constantly disturb the political and financial situation." (Dulles, 1922, p. 131)

For those officials in advanced economies not currently pressed to the wall, the problems of their colleagues stand as a reminder. In a world where there may be bounds on the government's capacity to extract taxation from the economy, or where there is a large option value to being able to sharply ramp up debt in response to wars, 
pandemics, or financial crises, officials may reasonably exhibit precautionary saving behavior in much the same way as that lauded among individuals. As our paper emphasizes though, governments have many options for bringing down debts, not just tightening budgets, and when debt is high and rising, it is important for policymakers to be aware of the full range of options they can eventually choose from, both orthodox and heterodox. 


\section{Appendix A: A chain-rule for the general government budget}

The IMF's Fiscal Monitor (various) reports the general government budgets of advanced economies adjusted for a variety of influences. These include the actual budget balance $(A C T)$, the primary budget-or the actual budget less interest payments (PRI), and the cyclically adjusted primary balance (CAP), which abstracts from both interest payments and the business cycle. The latter captures the discretionary element of fiscal policy. For our purposes, it is clearer to deal with the three elements of the budgetdiscretionary policy (DIS), interest payments (INT), and the cycle (CYC). Consider chain linking what the IMF reports and what we prefer:

$A C T=C A P+(A C T-P R I)+(P R I-C A P)$, or

$A C T=D I S+I N T+C Y C$.

The latter is reported below for changes over two four-year windows, from 2007 to 2010 and 2010 to 2013.

\begin{tabular}{|c|c|c|c|c|}
\hline \multicolumn{5}{|c|}{$\begin{array}{l}\text { Appendix: Decomposition of the change in the general budget balance } \\
\text { from } 2007 \text { to } 2010\end{array}$} \\
\hline & \multicolumn{2}{|c|}{$\begin{array}{l}\text { from } 2007 \text { to } 2010 \\
\text { Actual }\end{array}$} & \multicolumn{2}{|c|}{$\begin{array}{l}\text { from } 2010 \text { to } 2013 \\
\text { Actual }\end{array}$} \\
\hline & Change & Discretionary & Change & Discretionary \\
\hline Australia & -6.5 & -5.6 & 1.6 & 2.1 \\
\hline Austria & -3.5 & -1.0 & 3.0 & 2.8 \\
\hline Belgium & -3.9 & -2.8 & 1.3 & 1.5 \\
\hline Canada & -6.4 & -4.6 & 1.9 & 1.3 \\
\hline Czech Republic & -4.0 & -1.3 & 3.3 & 3.9 \\
\hline Denmark & -7.5 & -5.2 & 1.9 & 1.4 \\
\hline Finland & -7.8 & -3.0 & 0.4 & 1.1 \\
\hline France & -4.3 & -2.2 & 2.6 & 2.4 \\
\hline Germany & -4.4 & -2.9 & 4.4 & 3.5 \\
\hline Greece & -4.2 & -0.6 & 7.8 & 11.3 \\
\hline Hong Kong SAR & -3.4 & -3.0 & -3.5 & -1.9 \\
\hline Iceland & -15.5 & -7.6 & 8.0 & 5.8 \\
\hline Israel & -3.4 & -3.8 & 1.4 & 0.6 \\
\hline Italy & -2.8 & -0.8 & 1.3 & 3.4 \\
\hline Japan & -7.2 & -5.0 & 1.1 & 0.4 \\
\hline Korea & -0.6 & -0.3 & -0.9 & -0.6 \\
\hline Latvia & -8.0 & -1.6 & 6.2 & 2.6 \\
\hline Luxembourg & -4.4 & -1.5 & 0.8 & 1.0 \\
\hline Malta & -1.2 & -1.3 & 0.7 & 1.1 \\
\hline
\end{tabular}




$\begin{array}{lrrrr}\text { Netherlands } & -4.8 & -3.1 & 2.4 & 3.8 \\ \text { New Zealand } & -8.5 & -7.1 & 4.4 & 4.2 \\ \text { Norway } & -6.2 & -1.0 & -0.1 & 0.8 \\ \text { Portugal } & -6.6 & -5.6 & 4.9 & 8.4 \\ \text { Singapore } & -5.3 & -5.4 & -0.9 & -0.7 \\ \text { Slovak Republic } & -5.7 & -3.3 & 4.8 & 6.3 \\ \text { Slovenia } & -5.5 & -1.9 & -8.6 & 3.9 \\ \text { Spain1 } & -11.6 & -8.2 & 2.5 & 5.3 \\ \text { Sweden } & -3.6 & -1.6 & -1.3 & -1.5 \\ \text { Switzerland } & -1.2 & -0.7 & 0.0 & 0.3 \\ \text { United Kingdom } & -7.1 & -2.2 & 4.1 & 3.5 \\ \text { Source: IMF, Fiscal Monitor (2014). } & & & & \end{array}$




\section{Appendix B: Sensitivity of the interest rate to rare disaster probability with recursive utility}

In the text, we parameterize the effect of small changes in the probability of a rare disaster $p$ on the expected rate of interest, using the model of Barro (2006) with isoelastic utility. In this appendix, we follow the model of Barro (2009) and the parameterizations in Barro and Ursua (2012) to explore the more general case where the coefficient of relative risk aversion is not constrained to be the inverse of the elasticity of intertemporal substitution. We follow Barro (2009) who considers a variant of the Weil recursive utility function

$$
U_{t}=\left\{(1-\beta) C_{t}^{1-\theta}+\beta\left[(1-\beta)(1-\gamma) E_{t} U_{t+1}\right]^{(1-\theta) /(1-\gamma)}\right\}^{(1-\gamma) /(1-\theta)} /(1-\beta)(1-\gamma)
$$

where now $\gamma$ is the coefficient of risk aversion and $\theta$ is the inverse of the elasticity of intertemporal substitution. Assuming as before that rare disaster shocks lead to a permanent downward level shock in output, the equation for the short-term riskless expected real interest rate is now given by

$$
\begin{aligned}
r= & \rho+\theta g+(1 / 2)(\theta-\gamma) \cdot \sigma^{2}-(1 / 2) \theta \cdot \gamma \cdot \sigma^{2} \\
& +p \cdot(\theta-1) /(\gamma-1)-p \cdot E(1-b)^{-\gamma}+p \cdot[(\gamma-\theta) /(\gamma-1)] \cdot E(1-b)^{1-\gamma}
\end{aligned}
$$

where we have set $q=0$ since it has only a very minor effect. Equation (A2) reduces to equation ( 1 ) of the text when $\gamma=\theta$ (the isoelastic case) and $q=0$. Drawing on estimates from Barro and Ursua (2012), the sum of the coefficients on $p$ in equation (A2) is -1.54 if $\gamma=3$, and is -3.26 if $\gamma=4 .^{26}$ These estimates take $\theta=2, \sigma=.02, g=.025$ and $\rho=.044$. It should be noted that Barro and Ursua (2012) use a lower threshold for rare disasters than Barro (2006) (10\% instead of 15\%), which raises the sample value of $p$ to 0395 .

In the extended model, the sensitivity of the short-term interest rate $p$ falls somewhat (from -5.3 to between -1.54 and -3.26 ), but the basic qualitative conclusion of the text proves robust: small changes in the perception of a rare disaster can significantly affect the expected interest rate. Of course, the model does not allow for an explicitly time-varying disaster probability. For such an extension, see Wachter (2013), though since that model also gives a large effect on interest rates of a generalized rise in disaster probabilities, the basic insight should remain.

\footnotetext{
26 The sum of the coefficients on $p$ in (A2) is given by $\left[(\theta-1) /(\gamma-1)-E(1-b)^{-\gamma}+[(\gamma-\theta) /(\gamma-1)] \cdot E(1-b)^{1-\gamma}\right]$. The authors are grateful to Robert Barro for providing the intermediate calculations based on the full distribution of disaster outcomes $b$ necessary to calculate the coefficients on $p$ in equation (A2). (The mean value of $b$ is of course not sufficient since the equation is nonlinear in $b$.) For more general output processes, see Nakamura et al. (2013).
} 


\section{References}

Arcand, Jean-Louis, Enrico Berkes and Ugo Panizza. 2012. Too Much Finance? IMF Working Paper 12/161.

Aguiar, Mark, Manuel Amador, Emmanuel Farhi and Gita Gopinath. 2013. Crisis and commitment: Inflation credibility and the vulnerability to sovereign debt crises. Harvard University, June.

Alesina, Alberto and Silvia Ardagna. 1998. Tales of fiscal adjustment, Economic Policy, 13(27): 489-545.

Alesina, Alberto and Silvia Ardagna. 2009. Large changes in fiscal policy: Taxes versus spending. National Bureau of Economic Research, Working Paper No. 15438.

Azzimonti, Marina, Eva de Francisco and Vincenzo Quadrini. 2014. Financial globalization, inequality, and the rising public debt. American Economic Review 104(8): 2267-2302.

Ball and Mankiw. 1995. What Do Budget Deficits Do? Federal Reserve Bank of Kansas City, Symposium on Budget Deficits and Debt, August.

Barro, Robert J. On the determination of the public debt. 1979. The Journal of Political Economy 87(4): 940-971.

Barro, Robert J. 1997. Macroeconomics. MIT Press.

Barro, Robert J. 2006. Rare disasters and asset markets in the twentieth century. Quarterly Journal of Economics 121(3): 823-866.

Barro, Robert J. 2009. Rare disasters, asset prices, and welfare costs. American Economic Review 99(1): 243-64.

Barro, Robert J. and José F. Ursúa. 2012. Rare macroeconomic disasters. Annual Review of Economics 4(1): 83-109.

Bernanke, Ben S. 2005. The global savings glut and the U.S. current account deficit. Sandridge Lecture, Virginia Association of Economics, Richmond, Virginia, March 10.

Blanchard, Olivier. 1984. Current and anticipated deficits, interest rates and economic activity. European Economic Review 25(1): 7-27.

Bohn, Henning. 1998. The behavior of U.S. public debt and deficits. Quarterly Journal of Economics 113(3): 949-963. 
Bohn, Henning. 2008. The sustainability of fiscal policy in the United States. In Reinhard Neck and Jan-Egbert Sturm (eds.), Sustainability of Public Debt. MIT Press, Cambridge MA, 15-49.

Buttiglione, Luigi, Philip Lane, Lucrezia Reichlin and Vincent Reinhart. 2014. Deleveraging, What Deleveraging? $16^{\text {th }}$ Geneva Conference on Managing the World Economy, May 9, ICMB, CIMB and CEPR, Geneva.

Caballero, Ricardo, J. 2006. On the Macroeconomics of Asset Shortages. The Role of Money: Money and Monetary Policy in the Twenty-First Century, Andreas Beyer and Lucrezia Reichlin (eds.), 278-283. Fourth European Central Bank Conference, 9-10 November.

Checherita-Westphal, Cristina and Philipp Rother. 2012. The impact of high government debt on economic growth and its channels: An empirical investigation for the euro area. European Economic Review 56: 1405.

Davis, Lance E. and Robert Huttenback. 1988. Mammon and the Pursuit of Empire: The Political Economy of British Imperialism, 1860-1912. Cambridge: Cambridge University Press.

DeLong, Bradford and Lawrence Summers. 2012. Fiscal policy in a depressed economy. In David Romer and Justin Wolfers (eds), Brookings Papers on Economic Activity, Spring.

Dulles, John Foster. 1922. The allied debt. Foreign Affairs, September.

Edelstein, Michael 1981. "Foreign Investment and Empire 1860-1914," in Roderick Floud and Donald McCloskey (eds.) The Economic History of Britain since 1700, v. 2. Cambridge: Cambridge University Press.

Eichengreen, Barry. 1990. The capital levy in theory and practice. Public Debt Management: Theory and History, R. Dornbusch and M. Draghi (eds). New York: Cambridge University Press, 191-220.

Elmendorf, Douglas W. and N. Gregory Mankiw. 1999. Government debt. In Handbook of Macroeconomics, Vol. 1, J.B. Taylor and M. Woodford (eds). Elsevier Science, B.V., 1615-1699.

Ferguson, Roger W. and William L. Wascher. 2004. Distinguished lecture on economics in government: Lessons from past productivity booms. Journal of Economic Perspectives 18(Spring): 3-28.

Frieden, Jeffry. 2014. The Political Economy of Adjustment and Rebalancing. Mimeo, 
Harvard University, April.

Gabaix, Xavier. 2012. Variable rare disasters. The Quarterly Journal of Economics 127, 645-700.

Galbraith, John Kenneth. 1961. The Great Crash. New York: Time Inc.

Ghosh, Atish R., Jun I. Kim, Enrique G. Mendoza, Jonathan D. Ostry and Mahvash S. Qureshi. 2011. Fiscal Fatigue, Fiscal Space and Debt Sustainability in Advanced Economies. NBER Working Paper 16782, February.

Hall, George J. and Thomas J. Sargent. 2010. Interest Rate Risk and Other Determinants of Post-WWII US Government Debt/GDP Dynamics. NBER Working Paper 15702.

Hilscher, Jens, Alon Raviv, and Ricardo Reis. 2014. Inflating Away the Public Debt? An Empirical Assessment. NBER Working Paper 20339, July.

International Monetary Fund. 2010. World Economic Outlook, October, ch. 3

International Monetary Fund. 2013. Historical Public Debt Database.

http://www.imf.org/external/pubs/ft/wp/2010/data/wp10245.zip

International Monetary Fund. 2014. World Economic Outlook, October, ch. 4.

International Monetary Fund. Fiscal Monitor. Various issues.

International Monetary Fund. 2014. Fiscal Monitor, October.

Julliard, Christian, and Anisha Ghosh. 2012. Can rare events explain the equity premium puzzle? The Review of Financial Studies 25(10): 3037-3076.

Kaminsky, Graciela L. and Carmen M. Reinhart. 1999. The twin crises: The causes of banking and balance of payments problems. American Economic Review 89(3): 473-500.

Krugman, Paul. 2014. Currency regimes, capital flows, and crises. IMF Economic Review 63 (forthcoming).

Lucas, R. E. 1990. Why doesn't capital flow from rich to poor countries? American Economic Review 80(2): 92-96.

Madison, Angus. 1989. Dutch income in and from Indonesia 1700-1938. Modern Asian Studies 23: 645-670. 
Mauro, Paolo, Rafael Romeu, Ariel Binder, and Asad Zaman. 2013. Modern History of Fiscal Prudence and Profligacy. IMF Working paper 13/5, January.

Mendoza, Enrique G. and Jonathan D. Ostry. 2008. International evidence on fiscal solvency: Is fiscal policy 'responsible'? Journal of Monetary Economics 55(6), September, 1081-1093.

Mehra, Rajnish, and Edward C. Prescott. 1985. The equity premium: A puzzle. Journal of Monetary Economics 15(March): 145-161.

Mehra, Rajnish, and Edward C. Prescott. 1988. The equity risk premium: A solution? Journal of Monetary Economics 22(July), 133-136.

Mian, Atif, Amir Sufi, and Francesco Trebbi. 2010. The political economy of the US mortgage default crisis. American Economic Review 100(5): 1967-98.

Nakamura, Emi, Jón Steinsson, Robert Barro and José Ursúa, 2013. Crises and recoveries in an empirical model of consumption disasters. American Economic Journal: Macroeconomics 5(3), 35-74.

Nordhaus, William D. 1974. The falling share of profits. Brookings Papers on Economic Activity 1: 169-217.

Obstfeld, Maurice. 2013. On keeping your powder dry: Fiscal foundations of financial and price stability. Monetary and Economic Studies 31(November). Bank of Japan.

Obstfeld, Maurice and Kenneth Rogoff. 1996. Foundations of International Macroeconomics. Cambridge: MIT Press.

Qian, Rong, Carmen M. Reinhart and Kenneth Rogoff. 2011. On graduation from default, inflation and banking crises: Elusive or illusion? In Daron Acemoglu and Michael Woodford (eds), 2010 NBER Macroeconomics Annual. Chicago: University of Chicago Press.

Reinhart, Carmen M. 2010. This Time Is Different Chartbook: Country Histories on Debt, Default and Financial Crises. National Bureau of Economic Research, working paper 15815, March.

Reinhart, Carmen M. and Vincent Reinhart. 2011. After the Fall. In Macroeconomic Challenges: The Decade Ahead. Federal Reserve Bank of Kansas City Jackson Hole Symposium 2010.

Reinhart, Carmen M., Vincent Reinhart and Kenneth Rogoff. 2012. Public debt overhangs: Advanced-economy episodes since 1800. Journal of Economic Perspectives, 
26(3), 69-86.

Reinhart, Carmen M., and Kenneth Rogoff. 2008. This Time Is Different: A Panoramic History of Eight Centuries of Financial Crises. National Bureau of Economic Research Working paper 138882, March.

Reinhart, Carmen M., and Kenneth Rogoff. 2009. This Time Is Different: Eight Centuries of Financial Folly. Princeton, NJ: Princeton University Press.

Reinhart, Carmen M. and Kenneth S. Rogoff. 2010a. Growth in a time of debt. American Economic Review 100(2), May, 573-578.

Reinhart, Carmen M. and Kenneth S. Rogoff. 2010b. Growth and debt revisited. Voxeu, August.

Reinhart, Carmen M, and Kenneth S Rogoff. 2014. Financial and sovereign debt crises: Some lessons learned and those forgotten. In Financial Crises: Causes, Consequences, and Policy Responses, S. Claessens, M.A. Kose, L. Laeven, and F. Valencia (eds).

Reinhart, Carmen M, Kenneth Rogoff, and Miguel A Savastano. 2003. Debt intolerance. Brookings Papers on Economic Activity 1: 1-74.

Reinhart, Carmen and M. Belen Sbrancia. 2014. The liquidation of government debt. Economic Policy, forthcoming.

Rietz, T.A. 1988. The equity risk premium: A solution. Journal of Monetary Economics 22(July), 117-131.

Rodrik, Dani and Andres Velasco. 1999. "Short-Term Capital Flows." NBER Working Paper 7364. September.

Tanner, Evan. 2013. Fiscal Sustainability: A $21^{\text {st }}$ Century Guide for the Perplexed. IMF Working Paper WP 13/89, April.

Wachter, Jessica A. 2013. Can time varying risk of rare disasters explain aggregate stock market volatility? Journal of Finance 68(3), June, 987-1035.

Zhang, Ruixin, Thomas J. Brennan and Andrew W. Lo. 2014. The origin of risk aversion. Proceedings of the National Academy of Science 111 (50), 17777-17782. 